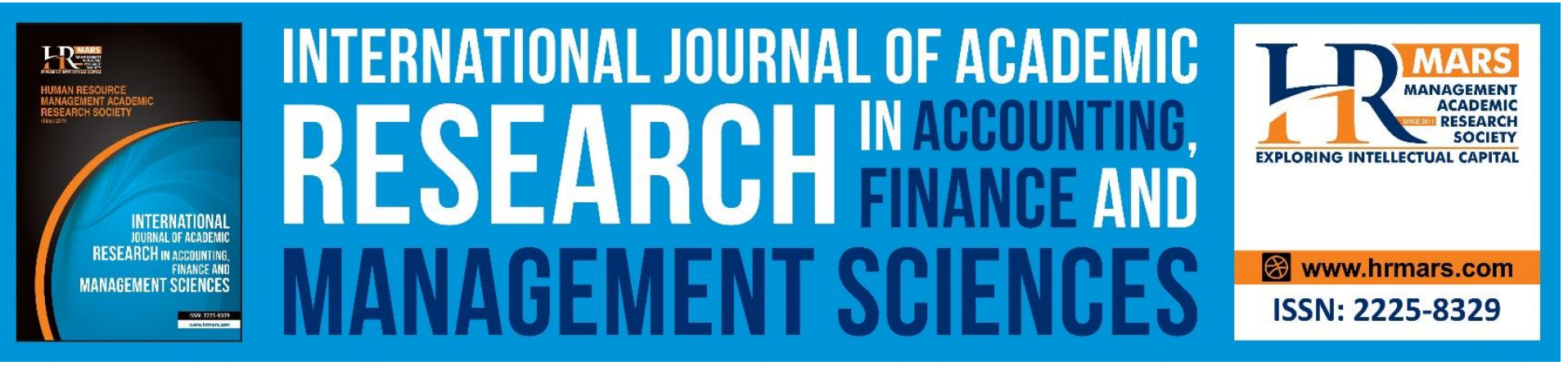

\title{
The Impacts of Covid-19 on Management and Discussion Analysis (MD \& A) Disclosures: Evidence in Malaysia
}

\section{Nurul Nazlia Jamil, Azreen Jihan Che Mohd Hashim}

To Link this Article: http://dx.doi.org/10.6007/IJARAFMS/v11-i3/10591 $\quad$ DOI:10.6007/IJARAFMS /v11-i3/10591

Received: 10 June 2021, Revised: 13 July 2021, Accepted: 29 July 2021

Published Online: 16 August 2021

In-Text Citation: (Jamil \& Hashim, 2021)

To Cite this Article: Jamil, N. N., \& Hashim, A. J. C. M. (2021). The Impacts of Covid-19 on Management and Discussion Analysis (MD \& A) Disclosures: Evidence in Malaysia. International Journal of Academic Research in Accounting Finance and Management Sciences, 11(3), 19-32.

Copyright: (c) 2021 The Author(s)

Published by Human Resource Management Academic Research Society (www.hrmars.com)

This article is published under the Creative Commons Attribution (CC BY 4.0) license. Anyone may reproduce, distribute, translate and create derivative works of this article (for both commercial and non-commercial purposes), subject to full attribution to the original publication and authors. The full terms of this license may be seen

at: http://creativecommons.org/licences/by/4.0/legalcode

Vol. 11, No. 3, 2021, Pg. 19 - 32

Full Terms \& Conditions of access and use can be found at http://hrmars.com/index.php/pages/detail/publication-ethics 


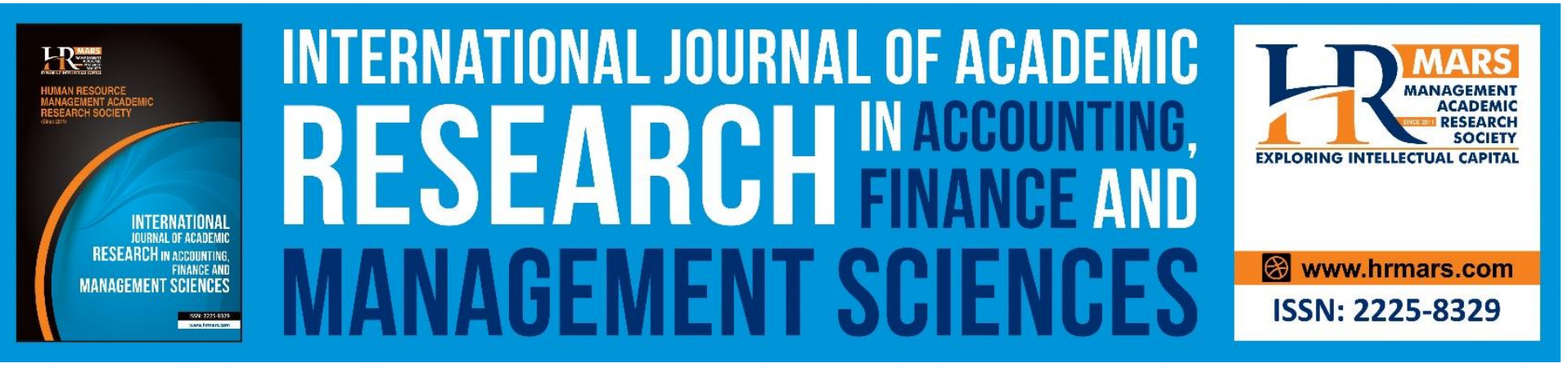

\title{
The Impacts of Covid-19 on Management and Discussion Analysis (MD \& A) Disclosures: Evidence in Malaysia
}

\author{
Nurul Nazlia Jamil, Azreen Jihan Che Mohd Hashim \\ Faculty of Economics and Muamalat, Universiti Sains Islam Malaysia \\ Email: nurulnazlia@usim.edu.my, azreenjihan@usim.edu.my
}

\begin{abstract}
As the Coronavirus (COVID-19) pandemic is predicted to plunge the global economy, the disclosure on the trends or uncertainties impacting the business operation and financial condition is deemed essential. One of the disclosure areas affected by COVID-19 is management discussion and analysis (MD\&A) which is urged to report current and potential future impact of the global pandemic to operations and financial conditions. In this paper, the study is to analyse the information of MD\&A disclosure whether the management stating their reaction in relation to COVID-19 implications. The quantitative methodology using secondary data has been utilized to conduct the study. Using a sample of 76 Malaysian public listed companies that made early disclosure on COVID-19 statement, the study employed sentiment analysis to code for the overall tone or sentiment statement made by the chairman/CEO in MD\&A. The finding shows that $40.8 \%$ ( $n=31$ firms) of the top management signals pessimistic reaction $(P), 21.1 \%$ ( $n=16$ firms) shows optimistic reaction $(0), 17 \%$ ( $n=13$ firms) shows realism reaction $(R)$ and $21.1 \%$ ( $n=16$ firms) provides no statement on COVID-19 in their MD\&A. The top management's reaction could serve as one of the communication mediums to signal positive, neutral or negative financial and economic anticipation. We believe the study is timely to provide such evidence as capital market regulators worldwide recently has called for the stock exchange operator to issue additional guidance for companies going forward to inform their shareholders and the investing public about the impacts of the COVID-19 pandemic. Further researches can be conducted to analyse any action taken by companies to modify their MD\&A disclosures to adequately capture all the elements of this developing situation and provide more information to users.
\end{abstract}

Keywords: Coronavirus, COVID-19, Pandemic, Management Discussion and Analysis, MD\&A

\section{Introduction}

Coronavirus (COVID-19) has become pandemic phenomena that very unexpected for the business globally. The economic smash of the COVID-19 outbreak inevitably invites extreme challenges for organization at all sectors across the global. As consequences, most companies are likely to be 
INTERNATIONAL JOURNAL OF ACADEMIC RESEARCH IN ACCOUNTING, FINANCE AND MANAGEMENT SCIENCES

Vol. 11, No. 3, 2021, E-ISSN: 2225-8329 @ 2021 HRMARS

impacted by the COVID-19 coronavirus pandemic (i.e; business operation and supply chain disruption, demand-supply mismatch, technology, and development of a resilient supply chain (Sharma, Adhikhary and Borah, 2020), decrease in product and service demand, overstocked inventory, liquidity shortfall, low human resources productivity) and the increased economic uncertainty and risk may also have significant financial reporting implications. According to Gould and Arnold (2020), there will be multiple financial reporting consequences which has to be considered by the financial statement preparers both in short and medium term. The management has to oversee the financial statement disclosures during post event of pandemic strike and ensure conclusive and informative disclosures are adequately made in order to provide information covering the whole business operation, risk and uncertainties, financial position, operating expenditures, the company's ability to fulfil financial obligation and other important areas.

Upon the demand for more transparent disclosure, the capital market player has made their effort to provide such information to ensure their existing and future investor are well informed and hence beneficial for their decision-making process. However, due to newness to the pandemic, some of the information related to COVID-19 disclosed by the listed issuers are still of no adequacy and needed proper guidance in order to provide best quality and adequacy of information (Broadstock et al, 2021). Considering the phenomenon, the pandemic has really impacted the accounting profession at various areas such as (i) the preparation of financial accounting and audit reporting (i.e; impairment of goodwill, impairment of long-lived assets, inventories and its net realizable value, impairment of receivables, loans and investments, debt modifications and loan covenants, revenue recognition, subsequent events recognition and disclosure); (ii) internal control considerations (i.e; control environment changes, assessing operating effectiveness, financial reporting operating resiliency); and (iii) management and board of director opinions (i.e; risk factors and management discussion and analysis (MD\&A).

Bursa Malaysia Securities Berhad (Malaysia stock exchange operator) has issued a disclosure guidance on COVID-19 related impacts and investments for listed companies, as part of their commitment to assist them during this challenging time. Whereas, in the United States (U.S), the Division of Corporation Finance and the Office of the Chief Accountant of the U.S. Securities and Exchange Commission (SEC) has also recently issued additional guidance and monitor how companies are disclosing the effects and risks of COVID-19 on their businesses, financial condition, and results of operations by supplementing CF Disclosure Guidance Topic No. 9 with guidance regarding additional disclosure considerations (Securities and Exchange Commission, 2020). The initiatives made by the regulators worldwide have allow the investors to evaluate the anticipated impact of COVID-19 through the disclosures made by the management and how the management and board of directors analyse COVID-19 implications.

Following to the new disclosure guidance issued to the stock issuer, we analyse the MD\&A disclosure made by the top management (i.e; Chairman or CEO) on their reaction with regards to the COVID-19 implications. The current study is using the tone of MD\&A to explore the reactions from the managements. The objective of this paper is to analyse the disclosure information made by the top management and board of directors, stating their reaction in relation to COVID-19 implications to the business in both current and future position. Using a sentiment analysis to code the tone of the top management (TOTM) towards COVID-19, we code the MD\&A into four categories (Pessimistic = P; Optimistic = O; Realism = R; and Exception = E). The management who issued a statement which signifies positivity and confidence with uncertain situation and believe to remain competitive is coded 
INTERNATIONAL JOURNAL OF ACADEMIC RESEARCH IN ACCOUNTING, FINANCE AND MANAGEMENT SCIENCES

Vol. 11, No. 3, 2021, E-ISSN: 2225-8329 @ 2021 HRMARS

as " $\mathrm{O}$ ". We coded " $\mathrm{P}$ " for the management who expressed strong concerns over what they perceive as the rising difficulty of conducting business, driven by trade conflicts, uncertainty and overregulation, among other worries. The management which expect the level of economic growth will remain about the same and will get back to normal as pandemic over is coded as " $R$ " and management which did not issue any statements relating to COVID-19 is coded as "E". We assessed to what extent the companies putting an effort to make their MD\&A useful to the shareholders by highlighting their reactions towards COVID-19 strike. We strongly believe that our paper provides the first evidence in the area of financial reporting in connection to COVID-19 impact and would be of great importance to the regulators.

This paper contributes to MD\&A disclosure literatures focusing on the reactions of management, which provide useful insights to the investor and regulator. Secondly the paper serves to be among the pioneer in the management reporting research area that document the evidence of COVID-19 implications which have not done in any of the previous researches. The remaining of the paper is organized as follows: Section 2 presents a literature review on MD\&A and COVID-19 impact, Section 3 discusses the methodology, Section 4 presents results and discussions and Section 5 discusses the implications of the study, describes the limitations and proposes some future research suggestions and concluded the paper.

\section{Literature Review}

COVID-19 has become pandemic phenomena that very unexpected for the business. It has resulted to the extreme challenges for organization at all sectors across the global. As consequences, the COVID-19 outbreak has changed on how the entities operate as the business are all under pressure to survive. The full impact of the pandemic to the business is yet to be seen with comparison already being made with the 2008 global financial crisis. The global health pandemic has once hit the world over few decades ago caused by coronaviruses known as Severe Acute Respiratory Syndrome (SARS) and impacted the global economic to suffer in 2003 (Brown and Smith, 2008). The study finds that SARS could have a catastrophic effect on the global economy. To date, it is documented that COVID19 pandemic has disrupted in global supply chains and has become one of the major issue associated with the economic costs of COVID-19 pandemic (Liu et al. 2020 and Albitar et al. 2020). The pandemic however does not stop at disrupting the business operation alone (i.e; supply chain activities) as other business areas are also affected including management disclosure, financial statement reporting and audit engagements (Gould and Arnold, 2020). Since the pandemic has caused unprecedented level of uncertainty about the economy, future earnings and many other inputs that represent fundamental elements of management and financial reporting, it is hence provide new challenge to the preparer to come out with adequate information. One of the crucial elements to cater during the pandemic crisis is the request for the capital market player to be open and transparent to the public, and promptly communicate with the investors and deliver the information upon which critical decisions will be made. The focus of this paper is to analyse the disclosure information made by the top management and board of directors, stating their reaction in relation to COVID-19 implications to the business in both current and future position.

As many studies relating to COVID-19 has ignored the area of management disclosure, this paper aims to be among the pioneer to document the evidence focusing on the reactions of management, which will provide useful insights to the investor and regulator on the importance of management 
INTERNATIONAL JOURNAL OF ACADEMIC RESEARCH IN ACCOUNTING, FINANCE AND MANAGEMENT SCIENCES

Vol. 11, No. 3, 2021, E-ISSN: 2225-8329 ๑ 2021 HRMARS

reactions and how they signal the existing and potential investors on the COVID-19 consequences. In addition, the company management should in the position to foresee the forthcoming crisis from the pandemic to issue a warning signal. The disclosure of the warnings should be highlighted in the Management' Discussion and Analysis (MD\&A) section in the financial report. This align with the purpose of MD\&A which is to provide an 'insider's view' of the company's financial performance. Thus, it is important for this paper to acknowledge what are the warning signals from the management and auditor towards the COVID-19. This outbreak phenomenon has given a new breath to the academic research into role of management and how asserting their professional judgment of the pandemic affecting the business into the financial report. Previous studies such as Ettredge et al. (2017); Sanoran (2018); Read and Yezegel (2018) have conducted research on how the global economic crisis gave substantial impact into auditor's reporting and going concern issues. Similar research direction can be taken in the case of COVID-19 impacting the professional judgement of the management in overcoming the crisis. The study highlighting the significant role of MD\&A section as a platform that offer discussion and analysis of company's business can be seen through the eyes of those who manage the business (Clarkson et al., 1999). The study believes the reactions from the government and each of every organization are the keys to combat the COVID-19 bad impact as the outbreak has severely affecting people and growing impact on the global economy. Therefore, this is very crucial for the management as the business leader to provide their perspective on the evolving situation and implications for their companies. They are expected to plan their business continuity and prepare forecast on their financial performance as the existing business analyses may not be capable of handling the fast moving and unknown variables of the outbreak like COVID-19. The companies should be able to focus on the factually and effective communication to the stakeholders as to minimize the risk of business disruptions. According to the Dharma (2020), the medium communication between the companies and market can be delivered through improvised MD\&A. Ideally, the tone and narratives of MD\&A provide influence the level of disclosure which strategically designed to meet the stakeholder's expectations.

The management play role to prepare detailed forecasts which given the nature of COVID-19 outbreak is rapidly growing, hence there is a need for the management to update regularly the assessment until the financial statements are officially issued. These forecast and assessment should reflect the analysis and management's plan and incorporated into the MD\&A in the financial report. The current study is using the tone of MD\&A to explore the reactions from the managements towards COVID-19 outbreak. Many previous studies such as Clarkson et al. (1999) conducted research on the text analysis of MD\&A, Lee and Park (2009) whom investigate the factors that may affect the tone variation, Feldman et al. (2010) conducted study on the incremental information provided by the 'tone change' and recent study form US, Caserio et al. (2019) have researched on whether financial companies of the USA are inclined to manipulate the MD\&A tone. Ideally, the tone of MD\&A has become a tool of disclosure in which can reduce the information asymmetry between the management and stakeholders.

\section{Research Methodology}

This unprecedented outbreak gives opportunities for the researcher to explore on the reactions of the management towards an effort combating the pandemic. In addition, there are varying responds between organization and individual towards the outbreak. Thus, to address the knowledge gap, 
INTERNATIONAL JOURNAL OF ACADEMIC RESEARCH IN ACCOUNTING, FINANCE AND MANAGEMENT SCIENCES

Vol. 11, No. 3, 2021, E-ISSN: 2225-8329 @ 2021 HRMARS

there are needs to conduct a research on the possible reactions using the MD\&A content as a tool to see the responds from the management and auditors.

This study performed sentiment analysis to gather information using the annual report from companies listed in Bursa Malaysia for the year 2019. The sample firms for this study is selected based on the available annual report published after $1^{\text {st }}$ March 2020, representing the early published annual report after World Health Organization (WHO) declared an outbreak of Covid 19 as pandemic, which may consequently have an impact to many sectors including business sectors. Hence, considering the available report as to date, there are about 76 sampled from various firms analyzed in the study. The information is derived from the MD\&A Report which is publicly available in Bursa Malaysia website (www.bursamalaysia.com).

The report is then analyzed by gathering the text statements relating to COVID-19 and verified by the independent coder to properly categorized the tone of management sentiment into four categorical of reactions. A list of words is coded into four categorical of reaction tone which are; Optimistic (O), Pessimistic (P), Realism (R) and Exception (E). The following table (Table 1) explained the reaction tone category. The study categorized MD\&A as Optimistic for the statement disclosure that signifies positive and very confidence outlook towards the economic growth and believe the uncertain situation is temporary. Pessimistic is coded to MD\&A which signifies the believe in economic to decline, perceive the uncertainties creates business difficulty, trade conflicts and significant economic diminish. Realism is coded to MD\&A which signifies the level of economic growth will remain about the same and shows the attitude or practice of accepting a situation as it is and they are being prepared to deal with it accordingly. MD\&A which provides no information about COVID19 is coded as Exception. The study provides the example of wordings extracted from MD\&A in the following table. 
INTERNATIONAL JOURNAL OF ACADEMIC RESEARCH IN ACCOUNTING, FINANCE AND MANAGEMENT SCIENCES

Vol. 11, No. 3, 2021, E-ISSN: $2225-8329$ @ 2021 HRMARS

\begin{tabular}{|c|c|c|}
\hline Reaction Tone & Sentiment & $\begin{array}{l}\text { Example from MD\&A } \\
\text { (Sources: Extracted from the } \\
\text { Annual Report) }\end{array}$ \\
\hline Optimistic (O) & $\begin{array}{l}\text { The statement in } \\
\text { MD\&A which signifies } \\
\text { the positive and very } \\
\text { confidence outlook } \\
\text { towards the economic } \\
\text { growth and believe } \\
\text { the uncertain } \\
\text { situation } \\
\text { temporary. }\end{array}$ & $\begin{array}{l}\text { i) The company believes the } \\
\text { impact of the pandemic is } \\
\text { manageable by the presence of } \\
\text { top management leadership } \\
\text { commitment } \\
\text { ii) The outlook for our precast } \\
\text { division remains promising } \\
\text { iii) The company will sustain its } \\
\text { prudent balance sheet growth } \\
\text { momentum }\end{array}$ \\
\hline Pessimistic (P) & $\begin{array}{l}\text { The statement in } \\
\text { MD\&A which signifies } \\
\text { the believe in } \\
\text { economic to decline, } \\
\text { perceive the } \\
\text { uncertainties creates } \\
\text { business difficulty, } \\
\text { trade conflicts and } \\
\text { significant economic } \\
\text { diminish. }\end{array}$ & $\begin{array}{l}\text { i) Demand for international } \\
\text { travel is expected to decline in } \\
\text { the near-term following the } \\
\text { imposition of travel restrictions } \\
\text { and widespread concerns } \\
\text { surrounding the cOVID-19 } \\
\text { outbreak } \\
\text { ii) the pandemic reduced } \\
\text { purchasing power and our } \\
\text { financial performance }\end{array}$ \\
\hline Realism (R) & $\begin{array}{l}\text { The statement in } \\
\text { MD\&A which signifies } \\
\text { the level of economic } \\
\text { growth will remain } \\
\text { about the same }\end{array}$ & $\begin{array}{l}\text { i) the Group is unable to reliably } \\
\text { estimate the financial impact of } \\
\text { COVID for the financial year } \\
\text { ending } 31 \text { December } 2020 \text { as } \\
\text { the pandemic has yet to run its } \\
\text { full course, hence the current } \\
\text { situation is still fluid } \\
\text { ii) the company is ready to face } \\
\text { them by maintaining and } \\
\text { improving our quality coupled } \\
\text { with more aggressive } \\
\text { promotion planning }\end{array}$ \\
\hline Exception (E) & $\begin{array}{l}\text { The statement in } \\
\text { MD\&A provides no } \\
\text { information about } \\
\text { COVID-19. }\end{array}$ & $\begin{array}{l}\text { Non-disclosure of covid } \\
\text { statement in MD\&A Statement }\end{array}$ \\
\hline
\end{tabular}

Table 1: Tone of Management Reaction 
INTERNATIONAL JOURNAL OF ACADEMIC RESEARCH IN ACCOUNTING, FINANCE AND MANAGEMENT SCIENCES

Vol. 11, No. 3, 2021, E-ISSN: 2225-8329 @ 2021 HRMARS

\section{Results and Discussion}

The assessment of management reaction is analysed through the final sample of 76 MD\&As of the Malaysian public listed firms. There are fourteen (14) industrial sectors included in the sample covering Construction $(n=2)$, Consumer Products \& Services $(n=15)$, Energy $(n=3)$, Exchange Traded Fund-Equity $(n=1)$, Financial Services $(n=8)$, Health Care $(n=1)$, Industrial Products \& Services $(n=$ 15), Plantation $(n=2)$, Property $(n=6)$, Real Estate Investment Trusts $(n=3)$, Technology $(n=6)$, Telecommunications \& Media $(n=4)$, Transportation \& Logistics $(n=6)$ and Utilities $(n=4)$. The details of the sample study are shown in Table 2.

\begin{tabular}{|l|l|l|l|}
\hline Industry & Frequency & Percent & $\begin{array}{l}\text { Cumulative } \\
\text { Percent }\end{array}$ \\
\hline Construction & 2 & 2.6 & 2.6 \\
\hline Consumer Products \& Services & 15 & 19.7 & 22.4 \\
\hline Energy & 3 & 3.9 & 26.3 \\
\hline Exchange Traded Fund-Equity & 1 & 1.3 & 27.6 \\
\hline Financial Services & 8 & 10.5 & 38.2 \\
\hline Health Care & 1 & 1.3 & 39.5 \\
\hline Industrial Products \& Services & 15 & 19.7 & 59.2 \\
\hline Plantation & 2 & 2.6 & 61.8 \\
\hline Property & 6 & 7.9 & 69.7 \\
\hline Real Estate Investment Trusts & 3 & 3.9 & 73.7 \\
\hline Technology & 6 & 7.9 & 81.6 \\
\hline Telecommunications \& Media & 4 & 5.3 & 86.8 \\
\hline Transportation \& Logistics & 6 & 7.9 & 94.7 \\
\hline Utilities & 4 & 5.3 & 100 \\
\hline Total & 76 & 100 & \\
\hline
\end{tabular}

Table 2: Study Sample

Overall, it is observed that the management sentiments are mostly pessimistic (40.8\%) indicating negative prediction towards the company's future position. Most of the top management highlighted their reactions in MD\&A by expressing strong concerns over what they perceive as the rising difficulty of operating the business that is caused by the global health pandemic, COVID-19. Our finding also shows $21.1 \%$ of the top management are optimistic by providing positive reactions indicating that the company is very confident in their prospects for revenue growth in the future despite the plunge of COVID-19. $17 \%$ of the management reacted that the business is at realism stage where the management believe the level of economic growth will remain about the same and the business is ready to accept the situation. From the 76 companies analysed, 16 companies (21.1\%) provided no statement with regard to COVID-19 in their MD\&A disclosure. The detail on the management reactions is tabulated in Table 3 below. 
INTERNATIONAL JOURNAL OF ACADEMIC RESEARCH IN ACCOUNTING, FINANCE AND MANAGEMENT SCIENCES

Vol. 11, No. 3, 2021, E-ISSN: 2225-8329 @ 2021 HRMARS

Table 3: Management Reaction Analysis

\begin{tabular}{|l|l|l|l|}
\hline $\begin{array}{l}\text { Management } \\
\text { Reaction }\end{array}$ & $\mathrm{N}$ & $\begin{array}{l}\text { Percen } \\
\mathrm{t}\end{array}$ & $\begin{array}{l}\text { Cumulative } \\
\text { Percent }\end{array}$ \\
\hline Pessimistic (P) & 31 & 40.8 & 40.8 \\
\hline Optimism (O) & 16 & 21.1 & 61.9 \\
\hline Realism I & 13 & 17.0 & 79.0 \\
\hline Exception I & 16 & 21.1 & 100 \\
\hline
\end{tabular}

The study is mainly reporting the descriptive data about the management's reaction towards COVID19 , hence the following table (Table $4 a, 4 b, 4 c$ ) reported in detail the sentiment analysis extracted from the MD\&A disclosure. Table $4 a$ shows the extracted statement with regard to pessimistic response (P), Table $4 \mathrm{~b}$ shows the extracted statement with regard to optimistic response (O), Table $4 \mathrm{c}$ shows the extracted statement with regard to realism response $\mathrm{I}$.

Table 4a tabulates the MD\&A disclosure and shows the extracted statement that is categorized as Pessimistic. Negative responses and reactions highlighted by the top management in MD\&A disclosure signals diminished confidence towards the financial and operation growth of the business. The management is being transparent to inform their stakeholders that the management predicted slow economic growth which might affect their major business area such as Customer (i.e; fall in business demand), Financial (i.e; poor financial performance, slow GDP, decrease cash flow) and Operation (i.e; business disruption, economic activity disruption). 
INTERNATIONAL JOURNAL OF ACADEMIC RESEARCH IN ACCOUNTING, FINANCE AND MANAGEMENT SCIENCES

Vol. 11, No. 3, 2021, E-ISSN: 2225-8329 @ 2021 HRMARS

\begin{tabular}{|c|c|c|}
\hline Extracted MD\&A disclosure & $\begin{array}{l}\mathrm{N} \\
\text { (firms) }\end{array}$ & Affected Business Area \\
\hline Business demand were impacted & 1 & Customer \\
\hline $\begin{array}{l}\text { Business demand were impacted and } \\
\text { Supply chain disruption }\end{array}$ & 4 & Customer \\
\hline $\begin{array}{l}\text { COVID-19 outbreak will have an impact on } \\
\text { the Group's financial performance. }\end{array}$ & 3 & Financial \\
\hline $\begin{array}{l}\text { Demand for international travel is expected } \\
\text { to decline in the near-term following the } \\
\text { imposition of travel restrictions and } \\
\text { widespread concerns surrounding the } \\
\text { COVID-19 outbreak }\end{array}$ & 2 & Customer \\
\hline Economic activity adverse impact & 1 & Operation \\
\hline Economic activity disruption & 1 & Operation \\
\hline $\begin{array}{l}\text { Gross Domestic Product growth to slow } \\
\text { down to negative } 1.9 \% \text { in } 2020\end{array}$ & 1 & Financial \\
\hline $\begin{array}{l}\text { It is expected to exacerbate existing } \\
\text { softening demand and pressure on margins } \\
\text { in the automotive retailing segment of the } \\
\text { premium luxury market }\end{array}$ & 1 & Customer \\
\hline Knock-on effect on sales & 1 & Customer \\
\hline $\begin{array}{l}\text { Major equity markets trended downwards } \\
\text { as concerns over contagion risks weighed on } \\
\text { sentiments, resulting in some shift in } \\
\text { investors' demand. }\end{array}$ & 1 & Financial \\
\hline The business will be challenging & 8 & Operation \\
\hline $\begin{array}{l}\text { The Covid-19 outbreak is expected to } \\
\text { adversely affect economic growth }\end{array}$ & 2 & Financial \\
\hline $\begin{array}{l}\text { the pandemic reduced purchasing power } \\
\text { and our financial performance }\end{array}$ & 1 & Financial \\
\hline $\begin{array}{l}\text { The revenue in the cash flows projection is } \\
\text { expected to decrease }\end{array}$ & 1 & Financial \\
\hline $\begin{array}{l}\text { We expect system loan growth to dip } \\
\text { slightly to } 3.6 \% \text { year-on-year in } 2020\end{array}$ & 1 & Financial \\
\hline We foresee temporary business disruption & 1 & Operation \\
\hline Weaker growth of economies & 1 & Operation \\
\hline Total firms & 31 & \\
\hline
\end{tabular}

Table 4a: Pessimistic Reaction

Around 16 firms in the sample provide confidence in economic growth despite the prediction of negative impact of COVID-19 to the business. Table 4b tabulates the MD\&A statement that signals 
INTERNATIONAL JOURNAL OF ACADEMIC RESEARCH IN ACCOUNTING, FINANCE AND MANAGEMENT SCIENCES

Vol. 11, No. 3, 2021, E-ISSN: 2225-8329 @ 2021 HRMARS

positive entailments. Most of the statements signalling confidence in economic growth and anticipate positive future business improvement.

\begin{tabular}{|l|l|}
\hline Extracted MD\&A disclosure & $\mathbf{N}$ (firms) \\
\hline Anticipate to continue grow positively in the coming years & 1 \\
\hline Confidence of financial position strength & 2 \\
\hline Optimistic of company's future prospects & 4 \\
\hline Positive business environment & 1 \\
\hline $\begin{array}{l}\text { The company believes the impact of the pandemic is } \\
\text { manageable }\end{array}$ & 2 \\
\hline $\begin{array}{l}\text { The company believes the impact of the pandemic is } \\
\text { manageable by the presence of top management } \\
\text { leadership commitment }\end{array}$ & 1 \\
\hline $\begin{array}{l}\text { The company will sustain its prudent balance sheet growth } \\
\text { momentum }\end{array}$ & 1 \\
\hline $\begin{array}{l}\text { The Group remains prudent in leading the organisation } \\
\text { through this crisis }\end{array}$ & 1 \\
\hline The outlook for our precast division remains promising & 1 \\
\hline The outlook will continue to remain favorable & 1 \\
\hline $\begin{array}{l}\text { We are seeing a more positive local economic } \\
\text { environment. }\end{array}$ & 1 \\
\hline Total & 16 \\
\hline
\end{tabular}

Table 4b: Optimistic Reaction

Table $4 c$ tabulates Realism reaction from the management. The management believes that the business to remain operating at the same level and operating as usual as they find COVID-19 is having minimal implications to their business operation and remain unaffected. The management set out immediate recovery plan to cope with the pandemic. 
INTERNATIONAL JOURNAL OF ACADEMIC RESEARCH IN ACCOUNTING, FINANCE AND MANAGEMENT SCIENCES

Vol. 11, No. 3, 2021, E-ISSN: 2225-8329 (C) 2021 HRMARS

\begin{tabular}{|l|l|}
\hline Extracted MD\&A disclosure & $\mathbf{N}$ (firms) \\
\hline $\begin{array}{l}\text { At LCT, we are closely monitoring the ongoing effects of } \\
\text { COVID-19 outbreak on the health and safety on our } \\
\text { employees, suppliers and contractors. }\end{array}$ & 1 \\
\hline $\begin{array}{l}\text { CMS is unable to fully estimate how these very recent } \\
\text { developments will affect the Group's businesses moving } \\
\text { forward. }\end{array}$ & 1 \\
\hline $\begin{array}{l}\text { Impact on our refineries have been minimal at this stage. } \\
\text { Trade remains unaffected and we have an ample stock at } \\
\text { hand to tide over any disruptions to the supply chain. }\end{array}$ & 1 \\
\hline $\begin{array}{l}\text { In the year 2020, revenue from the handling of cargoes and } \\
\text { vessel calls for LNG will still be the Group's main revenue } \\
\text { contributor while assessing the impact of the outbreak of } \\
\text { the Covid-19 }\end{array}$ & 1 \\
\hline $\begin{array}{l}\text { Our Company is closely monitoring the related risks and } \\
\text { potential impact as well as implementing necessary } \\
\text { measures to ensure our operations are running in a } \\
\text { sustainable manner }\end{array}$ & 1 \\
\hline $\begin{array}{l}\text { Ranhill has included measures in its Business Continuity } \\
\text { Plan (“BCP”) to ensure that the Group continues to operate } \\
\text { with minimal disruptions. }\end{array}$ & 1 \\
\hline $\begin{array}{l}\text { The company is ready to face them by maintaining and } \\
\text { improving our quality coupled with more aggressive } \\
\text { promotion planning }\end{array}$ & 1 \\
\hline $\begin{array}{l}\text { The Company remains committed to pursue its long-term } \\
\text { strategic programmes such as retail network expansion, } \\
\text { refinery and plant facilities upgrade, and supply chain } \\
\text { enhancement. }\end{array}$ & 1 \\
\hline $\begin{array}{l}\text { The Group has implemented innovative strategies to } \\
\text { survive any of such catastrophes }\end{array}$ & 1 \\
\hline $\begin{array}{l}\text { The Group is unable to reliably estimate the financial } \\
\text { impact of COVID for the financial year ending 31 December } \\
\text { 2020 as the pandemic has yet to run its full course, hence } \\
\text { the current situation is still fluid }\end{array}$ & 1 \\
\hline $\begin{array}{l}\text { The Management is aware of the recent outbreak of the } \\
\text { novel coronavirus, coVID-19 and is taking precautionary } \\
\text { actions by increasing the frequency of hygiene and cleaning } \\
\text { services }\end{array}$ & 1 \\
\hline $\begin{array}{l}\text { Ee have set up a TM COVID-19 Crisis Response Team and } \\
\text { activated our Crisis Communications Management Team to } \\
\text { actively monitor and support TM's operations on a daily } \\
\text { basis to help ensure business continuity and timely support } \\
\text { to meet customers' }\end{array}$ & 1 \\
\hline
\end{tabular}


INTERNATIONAL JOURNAL OF ACADEMIC RESEARCH IN ACCOUNTING, FINANCE AND MANAGEMENT SCIENCES

Vol. 11, No. 3, 2021, E-ISSN: 2225-8329 @ 2021 HRMARS

\begin{tabular}{|l|l|}
\hline $\begin{array}{l}\text { Which overall impact will depend on the duration and } \\
\text { spread of the outbreak as well as policy responses by the } \\
\text { authorities. }\end{array}$ & 1 \\
\hline Total & 13 \\
\hline
\end{tabular}

Table 4c: Realism Reaction

\section{Conclusion}

The objective of this paper is to analyse the disclosure information made by the top management and board of directors, stating their reaction in relation to COVID-19 implications to the business in both current and future position. Using a sentiment analysis to code the management reaction towards COVID-19, the study coded MD\&A disclosure into four categories pessimistic, optimistic, realism and exception. The finding shows that $40.8 \%$ of the top management signals pessimistic reaction, $21.1 \%$ shows optimistic reaction, $17 \%$ shows realism reaction and $21.1 \%$ provides no statement on COVID-19 in their MD\&A. The top management's reaction could serve as one of the communication medium to signal positive, neutral or negative financial and economic anticipation. We believe the study is timely to provide such evidences as capital market regulators worldwide recently has called for the stock exchange operator to issue additional guidance for companies going forward to inform their shareholders and the investing public about the impacts of the COVID-19 pandemic. The study is without the limitation. Small sample size employed in the study provides less generalized results. Bursa Malaysia has granted an extension of time of one month for the issuance of annual reports and annual audited financial statements by listed issuers has force our analysis to the only available annual reports at the time of data collection. Future study can enhance the study by covering more sample size. Future research also could extent the current study by investigating the impact of management reaction to the investor decision on their investment and shareholding activity.

\section{Acknowledgement}

This study is funded by the Malaysian Ministry of Education for FRGS Funding with Code: FRGS/1/2018/SS01/USIM/02/3 and Universiti Sains Islam Malaysia (USIM) with Code: USIM/FRGS/FEM/055002/51518 (Benchmarking Malaysian Private Entity Reporting Standard in Malaysia in Achieving High Income Nation).

\section{References}

Albitar, K., Gerged, A. M., Kikhia, H., \& Hussainey, K. (2020). Auditing in times of social distancing: the effect of COVID-19 on auditing quality. International Journal of Accounting \& Information Management.

Broadstock, D. C., Chan, K., Cheng, L. T., \& Wang, X. (2021). The role of ESG performance during times of financial crisis: Evidence from COVID-19 in China. Finance research letters, 38, 101716.

Caserio, C., Panaro, D., \& Trucco, S. (2019). Management discussion and analysis: a tone analysis on US financial listed companies. Management Decision.

Clarkson, P. M., Kao, J. L., \& Richardson, G. D. (1999). Evidence that management discussion and analysis (MD\&A) is a part of a firm's overall disclosure package. Contemporary accounting research, 16(1), 111-134. 
INTERNATIONAL JOURNAL OF ACADEMIC RESEARCH IN ACCOUNTING, FINANCE AND

MANAGEMENT SCIENCES

Vol. 11, No. 3, 2021, E-ISSN: 2225-8329 @ 2021 HRMARS

Dharma, F. (2020). Investor reaction to earnings announcements moderated by management discussion and analysis (MD\&A). In The Future Opportunities and Challenges of Business in Digital Era 4.0 (pp. 159-162). Routledge.

Ettredge, M., Fuerherm, E. E., Guo, F., \& Li, C. (2017). Client pressure and auditor independence: Evidence from the "great recession" of 2007-2009. Journal of Accounting and Public Policy, 36(4), 262-283.

Feldman, R., Govindaraj, S., Livnat, J., \& Segal, B. (2010). Management's tone change, post earnings announcement drift and accruals. Review of Accounting Studies, 15(4), 915-953.

Gould, S., \& Arnold, C. (2020). The financial reporting implications of Covid-19. IFAC/Suppoerting Financial Standards.

Keogh-Brown, M. R., \& Smith, R. D. (2008). The economic impact of SARS: how does the reality match the predictions?. Health policy, 88(1), 110-120.

Lee, J., \& Park, J. (2019). The impact of audit committee financial expertise on management discussion and analysis (MD\&A) tone. European Accounting Review, 28(1), 129-150.

Liu, Y., Lee, J. M., \& Lee, C. (2020). The challenges and opportunities of a global health crisis: the management and business implications of COVID-19 from an Asian perspective. Asian Business \& Management, 1.

Read, W. J., \& Yezegel, A. (2018). Going-concern opinion decisions on bankrupt clients: Evidence of long-lasting auditor conservatism?. Advances in Accounting, 40, 20-26.

Sanoran, K. L. (2018). Auditors' going concern reporting accuracy during and after the global financial crisis. Journal of Contemporary Accounting \& Economics, 14(2), 164-178.

Sharma, A., Adhikary, A., \& Borah, S. B. (2020). Covid-19' s impact on supply chain decisions: Strategic insights from NASDAQ 100 firms using Twitter data. Journal of Business Research, 117, 443449. 